\title{
Effect of Different Levels of Pulsing Concentrations on Vase Life of Gladiolus (Gladiolus grandiflorus L.)
}

\author{
Sachi Gupta* and Ashok Kumar
}

Department of Floriculture and Landscape, College of Horticulture and Forestry, Narendra Deva University of Agriculture and Technology, Faizabad-224229, India

*Corresponding author

\section{A B S T R A C T}

\section{Keywords}

Pulsing, Sucrose, Floret, Spike, Vase life

Article Info

Accepted:

04 August 2018

Available Online:

10 September 2018
An investigation was carried out to standardize the effect of pulsing concentration on vase life of gladiolus (Gladiolus grandiflorus L.) cv. White prosperity during the year 20172018. Spikes were harvested at early in the morning having 1-2 florets showed colour from the main experiment field. The maximum 10.33 days vase-life of flower was found with continuous opening of florets, increase in spike length, absorption of vase solution, first increase thereafter decreased, and moderate florets drooping could be observed, when gladiolus spikes were pulsed in to $20 \%$ pulsing solution for 24 hours.

\section{Introduction}

Gladiolus (Gladiolus grandiflorus L.) is an important floral crop being grown commercially all over the country under varying climatic condition and an important cut flower both in domestic and international market. It stands fourth in the international cut flower trade. It has gained much importance as "Queen of bulbous flower". Globally, large scale production of gladiolus flowers is seen in USA, Holland, Italy, France, etc. In India, it is commercially grown in West Bengal, Himachal Pradesh, Sikkim, Karnataka, Uttar Pradesh, Tamil Nadu, Punjab, Delhi, Tripura, Assam, Manipur, Meghalaya and Nagaland. The beauty, fragrance, wide range of colour and form make them the most attractive group among bulbous flowers. The changing life style of Indians with a tendency to "say it with flower" and celebration of festivals like Valentine's day, Christmas, Mather's day has created a tremendous demand of cut flowers like rose, carnation, gerbera, gladiolus, and tuberose. In cut flower industry, the most important aspect is post-harvest handling in order to maintain freshness and original colour of the flowers for longer period after harvest. Generally, gladiolus flower spikes last for 7-8 days in tap water (Singh and Sharma, 2003, Singh et al., 2008). The qualitative and quantitative post-harvest losses of gladiolus can be reduced by adopting improved technologies like harvesting at proper stage, use of floral preservatives and bud opening solution, pulsing, precooling, improved 
storage techniques such as low temperature storage, proper packaging methods etc. Use of floral preservatives is the most economical and practical method to enhanced post-harvest life of gladiolus spikes (Salunkhe et al., 1990). Pulsing is found to be a great value in promoting flower opening, prolonging life and improving floret size of gladiolus spikes. Studies have also revealed that sucrose promotes opening of immature florets of gladiolus (Singh et al., 2001). Several attempts have been made to study the effect of different chemicals and sugars on the longevity and economic value of cut flowers (Halevy and Mayak, 1979), Kumar and Deen (2017) advocated that sucrose is useful as a respiratory substrate as an osmolite that helps in the maintenance of a favourable water balance. Investigations pertaining to improve the vase-life of cut flowers by the chemical treatments after harvest have been made with varying success. Keeping in view the importance of pulsing solution present investigation had been conducted to assess the effect of pulsing concentrations on vase life of gladiolus.

\section{Materials and Methods}

The present investigation was standardization the effect of different levels of pulsing concentrations on vase life of gladiolus (Gladiolus grandiflorus L.) cv. White prosperity was conducted at post graduate laboratory of Department of Floriculture and Landscape, College of Horticulture and Forestry, Narendra Deva University of Agriculture and Technology, Faizabad (U.P.), India during 2017-18. The spikes were procured from gladiolus field at Main Experiment Station of Department of Floriculture and Landscape. The site falls under humid sub-tropical climate and is located in between $24.47^{0}$ and $26.56^{\circ} \mathrm{N}$ latitude and $82.12^{\circ}$ and $83.98^{\circ} \mathrm{E}$ longitude at an altitude of $113 \mathrm{~m}$ above the mean sea level in the Gangetic Alluvial Plains of Eastern Uttar Pradesh. The site receives $1150 \mathrm{~mm}$ average annual rainfall out of which nearly 75 per cent rainfall occurs during June to August/September months of the year. The experiment was conducted with six treatments i.e. various concentration of sucrose $(0 \%, 5 \%$, $10 \%, 15 \%, 20 \%$ and $25 \%)$. The spikes were harvested at 1-2 floret showed colour in morning by sharp knife and brought to laboratory into bucket containing distilled water. In laboratory $3 \mathrm{~cm}$ lower portion of the spikes were removed by making slanting cut and pulsed into treatments wise of pulsing solution for 24 hours. There after spikes were put into vase containing $5 \%$ sucrose solution and observations were recorded on percent opening of florets, increase in spike lengths, drooping of floret, absorption of vase solution and vase life of flower at alternate days.

\section{Statistical analysis}

The experiment was conducted in Completely Randomized Design with 6 treatments and 3 replications during vase-life study. The collected data were analyzed to find out the significant treatment at 5\% and 1\% (Panse and Sukhatme, 1985).

\section{Results and Discussion}

Data as embodied in Table 1, clearly reveals that the maximum florets opened were recorded with $20 \%$ sucrose on 10 th day of observation. The maximum floret opening was continuously increased till end of the experiment with sucrose was due to the favourable osmotic pressure and carbohydrate concentrations and water uptake. Sucrose increase the osmotic potential and improves their ability to take up maintain turgidity (Acock and Nichols, 1979) and (Halevy and Mayak, 1974). Kumar and Deen (2015) also reported that the opening of florets were maximum with $20 \%$ sucrose as a pulsing 
solution. The different level of pulsing concentration showed significant effect on increase in spike length over control. The increase in spike length ranged from 0.12 to $4.89 \%$. The maximum increase in spike length $(4.89 \%)$ was observed with $\mathrm{T}_{5}(20 \%$ sucrose) followed by $\mathrm{T}_{6}(25 \%$ sucrose $)$ while it was lowest in control $(0.12 \%)$. On the $10^{\text {th }}$ day of vase life maximum increase is in the $\mathrm{T}_{5}$ (20\% sucrose) of $3.22 \%$. The continuous increase in spike length in all the treatments, it is observed that cell division and elongation were continued in spikes even after harvesting. Similar result was also reported by Kumar and Deen (2015) in tuberose.
There was no drooping was recorded till 4th day of observation and there after a progressive increase in florets drooping up till end of the experiment. The minimum drooping was observed with $20 \%$ sucrose on $10^{\text {th }}$ day it was $60.65 \%$ that might be because the fact that sucrose acts as carbon source, maintains mitochondrial structure and provide longer period energy to delay the senescence of florets (Halevy and Mayak, 1981; Kaur et al., 2006). Similarly, increase in drooping of florets with advancement of period has been reported in tuberose flower (Kumar and Deen, 2015). These reported observations supported the present findings.

Table.1 Effect of different levels of pulsing concentrations on Gladiolus

\begin{tabular}{|c|c|c|c|c|c|c|c|c|c|c|}
\hline \multirow[t]{2}{*}{ Treatments } & \multicolumn{5}{|c|}{ Opening of florets (\%) } & \multicolumn{5}{|c|}{ Increase in spike length (\%) } \\
\hline & $\begin{array}{l}2^{\text {nd }} \\
\text { day }\end{array}$ & $\begin{array}{l}4^{\text {th }} \\
\text { day }\end{array}$ & $\begin{array}{l}6^{\text {th }} \\
\text { day }\end{array}$ & $\begin{array}{l}8^{\text {th }} \\
\text { day }\end{array}$ & $10^{\text {th }}$ day & $2^{\text {nd }}$ day & $4^{\text {th }}$ day & $6^{\text {th }}$ day & $8^{\text {th }}$ day & $10^{\text {th }}$ day \\
\hline$T_{1}$ & 15.19 & 26.60 & 63.43 & 84.12 & 84.91 & 0.65 & 0.46 & 0.12 & 0.60 & 0.25 \\
\hline $\mathbf{T}_{2}$ & 15.19 & 26.31 & 52.79 & 81.71 & 86.53 & 0.74 & 0.55 & 0.89 & 0.78 & 0.56 \\
\hline $\mathrm{T}_{3}$ & 8.02 & 25.52 & 52.56 & 81.66 & 89.65 & 1.36 & 0.55 & 1.53 & 1.28 & 1.19 \\
\hline $\mathbf{T}_{4}$ & 7.97 & 21.81 & 35.04 & 77.47 & 92.48 & 2.87 & 1.44 & 3.16 & 1.38 & 0.42 \\
\hline$T_{5}$ & 7.93 & 16.23 & 34.12 & 74.99 & 94.99 & 6.20 & 6.60 & 6.02 & 4.89 & 3.22 \\
\hline$T_{6}$ & 2.38 & 15.94 & 32.53 & 72.52 & 94.58 & 3.49 & 4.43 & 4.26 & 2.04 & 1.09 \\
\hline SEm \pm & 1.12 & 1.29 & 1.59 & 1.42 & 2.29 & 0.27 & 0.25 & 0.18 & 0.28 & 0.32 \\
\hline \multirow[t]{2}{*}{ CD at $1 \%$} & 4.87 & 5.57 & 6.89 & 6.13 & 9.91 & 1.17 & 1.08 & 0.79 & 1.22 & 1.39 \\
\hline & \multicolumn{5}{|c|}{ Drooping of florets (\%) } & \multicolumn{5}{|c|}{ Absorption of vase solution (\%) } \\
\hline $\mathbf{T}_{1}$ & 16.39 & 34.12 & 57.93 & 65.86 & 76.19 & 0.28 & 0.64 & 1.75 & 3.37 & 0.92 \\
\hline $\mathbf{T}_{2}$ & 15.12 & 32.37 & 52.39 & 62.44 & 75.08 & 0.33 & 1.01 & 1.80 & 3.69 & 0.94 \\
\hline $\mathbf{T}_{3}$ & 8.02 & 30.03 & 52.13 & 59.95 & 74.99 & 0.33 & 1.02 & 4.51 & 4.52 & 1.27 \\
\hline$T_{4}$ & 7.94 & 27.38 & 50.00 & 57.53 & 69.96 & 0.34 & 1.03 & 5.20 & 5.74 & 1.21 \\
\hline$T_{5}$ & 7.50 & 26.30 & 44.81 & 52.69 & 60.65 & 0.66 & 4.41 & 8.86 & 12.78 & 1.53 \\
\hline$T_{6}$ & 7.27 & 26.31 & 44.59 & 52.79 & 60.76 & 0.56 & 1.38 & 5.31 & 8.01 & 1.25 \\
\hline SEm \pm & 0.566 & 1.056 & 1.01 & 1.03 & 1.49 & 0.074 & 0.15 & 0.20 & 0.33 & 0.30 \\
\hline CD at $1 \%$ & 2.44 & 4.56 & 4.37 & 4.44 & 6.45 & 0.32 & 0.66 & 0.87 & 1.44 & 1.30 \\
\hline \multicolumn{11}{|c|}{$\mathrm{T}_{1}$ - Distilled water (Control), $\mathrm{T}_{2}-5 \%$ sucrose, $\mathrm{T}_{3}-10 \%$ sucrose, $\mathrm{T}_{4}-15 \%$ sucrose, $\mathrm{T}_{5}-20 \%$ sucrose, $\mathrm{T} 6-25 \%$ sucrose } \\
\hline & \multicolumn{4}{|c|}{ Average Vase life of spike } & & & & & & \\
\hline $\mathbf{T}_{1}$ & \multicolumn{4}{|c|}{5.00} & & & & & & \\
\hline$T_{2}$ & \multicolumn{4}{|c|}{6.00} & & & & & & \\
\hline $\mathbf{T}_{3}$ & \multicolumn{4}{|c|}{6.33} & & & & & & \\
\hline $\mathbf{T}_{4}$ & \multicolumn{4}{|c|}{7.00} & & & & & & \\
\hline $\mathbf{T}_{5}$ & \multicolumn{4}{|c|}{10.33} & & & & & & \\
\hline $\mathrm{T}_{6}$ & \multicolumn{4}{|c|}{10.00} & & & & & & \\
\hline SEm \pm & \multicolumn{4}{|c|}{0.19} & & & & & & \\
\hline CD at $1 \%$ & \multicolumn{4}{|c|}{0.83} & & & & & & \\
\hline
\end{tabular}


It can be seen from the data presented in Table, on absorption of vase solution during vase-life study. The absorption of vase solution was recorded increasing trend up to $8^{\text {th }}$ day of observation, there after absorption was decreased with advancement of periods. The increased of absorption of vase solution might be due to first increase the physiological activities like opening of florets and spike length, might be due to fact that sucrose provides necessary energy for physiological activities needed for uptake of vase solution. There after the decrease in absorption of vase solution with advancement of vase-life periods might be due to decrease florets opening rates as well as increase the drooping of florets. Hutchinson et al., (2003) also found that pulsing of tuberose cut flower for $24 \mathrm{hrs}$. in sucrose to prove their water relation. Similar result reported by Ali et al., (2008) in cut daffodil flower, who found that vase solution as distilled water uptake was first increased thereafter decreases sharply after $6^{\text {th }}$ day of observation.

Observations presented in Table, reveals that maximum (10.33 days) vase-life was recorded with $20 \%$ sucrose solution which was significantly higher in comparison to $\mathrm{T}_{1}, \mathrm{~T}_{2}$, $\mathrm{T}_{3}, \mathrm{~T}_{4}$, and $\mathrm{T}_{6}$ treatments. The longer vase-life might be because of longer period florets opening, maximum spike weight and minimum drooping of florets with $20 \%$ sucrose. Drooping of 5th florets was recorded as a day of vase-life of flower. Paull and Goo (1982) reported sucrose as a pulsing treatment has been also found to improve the vase-life of anthurium. Similar results also reported by Kumar and Deen (2015) used 20\% sucrose as a pulsing solution found that maximum vaselife of tuberose.

It can be concluded from the above experimental results indicated that spikes harvested at 1-2 floret colour show stage and pulsing in to $20 \%$ sucrose solution for $24 \mathrm{hrs}$ would give maximum 10.33 days vase-life with continuous higher florets opening, maximum increase in spike length and minimum florets drooping when put in to $5 \%$ sucrose as a vase solution at room temperature.

\section{References}

Acock B, Nichols R. (1979). Effect of sucrose on water relation of senescing carnation flowers. Annals of Botany. 44:221-230.

Ali S, Khan F.U., Khan F.A, and Wani S.A. (2008). Post-harvest behaviour of cut daffodil as influenced by certain pulsing treatment. Journal of Ornamental Horticulture, 11 (2): 81-90.

Halevey A.H, Mayak, S.S. (1979). Senescence and post-harvest physiology of cut flowers. Part 1 Horticultural Review. 1:204-236.

Halevey, A. H, and Mayak, S.S. (1981). Senescence and post-harvest physiology of cut flowers. Part 2 Horticulture Reviews. 3:59-143.

Halvey A.H, Mayak, S.S. (1974). Improvement of cut flower quality and longevity of preship treatment. Acta Horticulture. 43:355-357.

Hutchinson, M.J., Chebet, D.K., Emongor, V.E. (2003). Effect of ACCEL, sucrose and silver thiosulphate on the water relations and post-harvest physiology of cut tuberose flowers. Acta Horticulture. 562:159-197.

Kaur, G, Singh, P, Parmar, V. (2006). Change in sugar metabolism in gladiolus tritis during senescence as affected by ethylene and its antagonists. Journal of Plant Science Research, 22:81-89.

Kumar, A., Deen B. (2017). Effect of ecofriendly vase solution on maximum buds opening and longer vase-life of tuberose (Polianthes tuberosa L.) cv. Hydrabad Duble, Journal of 
Pharmacognosy and Phytochemistry. 6(4): 1233-1236.

Kumar, A., Deen, B. (2015). Effect of pulsing solutions on maximum buds opening and vase-life of tuberose (Polianthes tuberosa L.) cv. Hydrabad Duble. Annals of Plant and Soil Research. 17(special issue):197-200.

Paull, R. E., Goo, T.T.C. (1982). Pulse treatment with silver nitrate extends the vase-life of anthurium. Journal of American Society of Horticultural Science. 107:842-844.

Salunkhe, D. K, Bhat, N. R., Desai, B. B. (1990). Post-harvest biotechnology of flowers and ornamental plants. Springer-Verlag, Berlin. 349-412
Singh, A., Kumar, J., Kumar, P. (2008). Effect of plant growth regulators and sucrose on post-harvest physiology, membrane stability and vase life of cut spikes of gladiolus. Plant Growth Regulator. 55: 221-229.

Singh, K., Singh, P.J., Arora, J. S., Mann, R.P.S. (2001). Effect of vase solutions on keeping quality of different grades of gladiolus. Journal of Ornamental Horticulture, New Series. 17: 23-25.

Singh, P.V., Sharma, M. (2003). The postharvest life of pulsed gladiolus spikes; the effect of preservative solutions. Acta Horticulture. 624: 395-398.

\section{How to cite this article:}

Sachi Gupta and Ashok Kumar. 2018. Effect of Different Levels of Pulsing Concentrations on Vase Life of Gladiolus (Gladiolus grandiflorus L.). Int.J.Curr.Microbiol.App.Sci. 7(09): 330334. doi: https://doi.org/10.20546/ijcmas.2018.709.040 